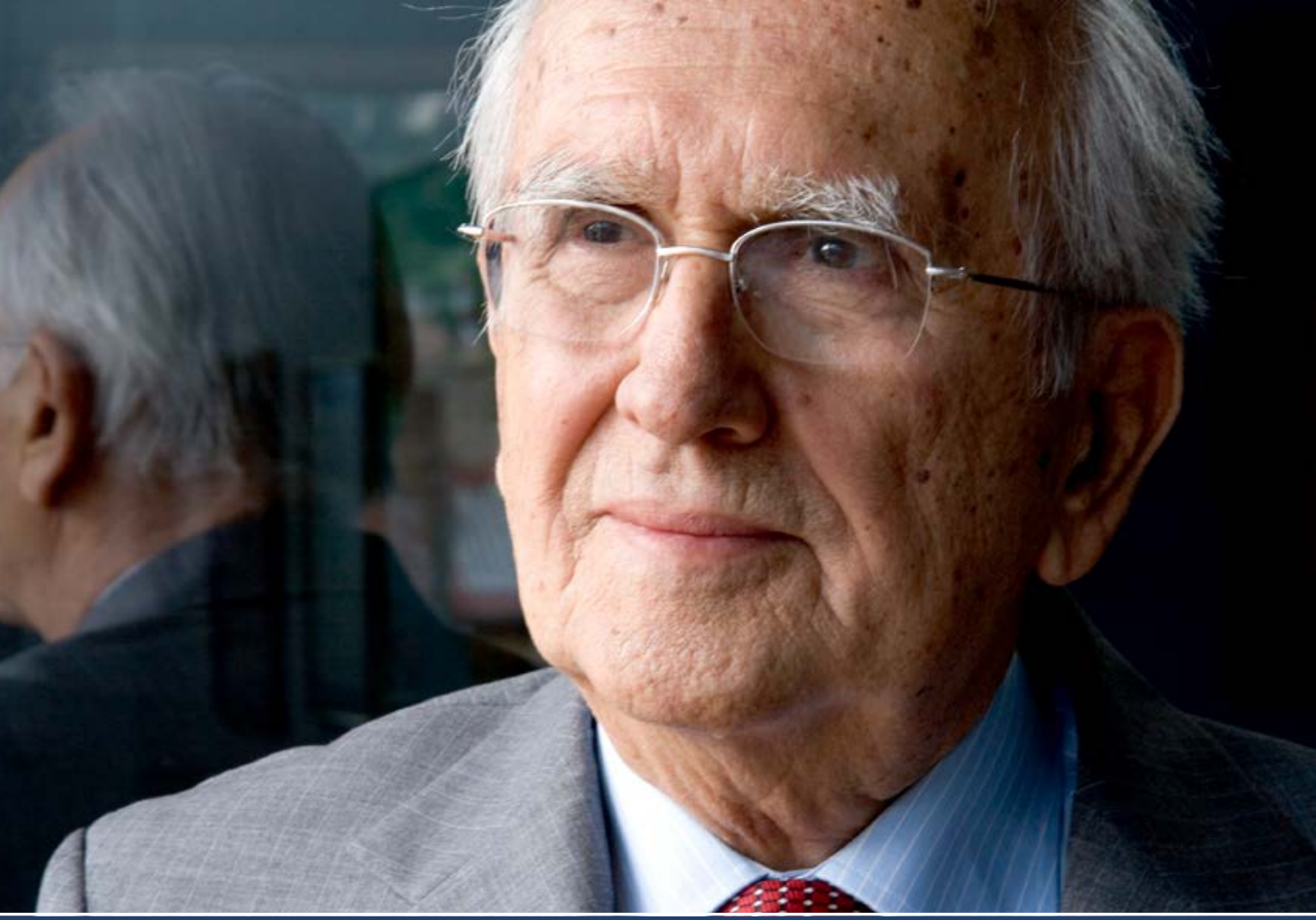

\title{
Politički pluralizam i demokratizacija Jugoslavije
}

Vanr. prof. dr. Admir Mulaosmanović

97-107.

Adil Zulfikarpašić i liberalne političke inicijative ZBORNIK RADOVA 



\title{
Politički pluralizam i demokratizacija Jugoslavije
}

\author{
Prof. dr. Admir Mulaosmanović \\ Fakultet za umjetnost i društvene nauke Internacionalnog \\ univerziteta u Sarajevu \\ amulaosmanovic@ius.edu.ba
}

SAŽETAK: U ovome članku se razmatra politički razvitak Adila Zulfikarpašića i njegova uloga tokom procesa demokratizacije u Jugoslaviji, odnosno Bosni i Hercegovini. Dat je presjek nastanka komunisticke ideje u Bosni i Hercegovini tridesetih i četrdesetih godina 20. stoljeća, kao i njenih nosilaca, među kojima je bio i Zulfikarpašić. Značaj te ideologije, zajedno s događajima iz Drugog svjetskog rata, za Zulfikarpašića je velik jer je stajala na putu njegove potpune političke izgrađenosti i bila je „provokator” njegovog daljnjeg idejnog oblikovanja. Kao jasno orijentiran liberal evropskog podneblja, predstavljao je istinski dašak demokratije tokom promjene društveno-političkih odnosa, a za Bošnja- ke bio dokazom njihove želje za istinski demokratskim društvom i poretkom. Upravo s ovih liberalnih temelja, potpuno nacionalno osviješten i posvećen Bosni i Hercegovini, Adil Zulfikarpašić je tokom boravka u Švicarskoj nastojao djelovati i sarađivati s jugoslavenskom emigracijom i politickim disidentima koji su boravili u evropskim zemljama. Na tom iskustvu gradio je i vlastiti odnos prema politickoj zbilji u Jugoslaviji i pristup u nalaženju rješenja za dramu koja se odvijala.

KLJUČNE RIJEČI: demokratizacija, Jugoslavija, Adil Zulfikarpašić, Bosna i Hercegovina, politika, Stranka demokratske akcije

\section{Uvod}

Demokratski procesi u SFR Jugoslaviji nakon pada komunističkih režima u Centralnoj i Istočnoj Evropi imali su karakteristiku povratka korijenu, pri čemu se misli na svojevrsno resetovanje prošlosti i povratak na sami početak stvaranja zajedničke države Južnih Slavena tokom i netom nakon Prvog svjetskog rata. Sama ta činjenica, ukoliko se prihvati kao takva, svjedočila je o teškom bremenu koje se nalazilo na plećima južnoslavenskih političkih elita i izazovima pred kojima su se nalazile. Prosto kazano, nezadovoljstvo - ako ne svih, onda većine - potvrđivalo je jednostavnu stvar. Od samoga 
početka je društveno-politički razvoj išao nedemokratski i odvijao se na način koji je malo koga zadovoljavao. Zadovoljštinu je, pak, predstavljao različit spektar mogućnosti koje su se otvarale i to različitim društvenim stratama. Najznačajnije pitanje bilo je ono nacionalno, pa je tako spektar išao od nezadovoljstva srpskih predstavnika zbog neostvarivanja velike srpske države, preko hrvatskih, koji su željeli više autonomije i teritorije, do onih, uvjetno kazano, manje bitnih grupa i etniciteta koji su sanjali sigurnost, i skoro ništa više.

Ukupna jugoslavenska javnost sve više je postajala svjesna prijetnje nestanka zajedničke države, koju su neminovno nosili teški politički procesi. Okovana programima političkih elita - slovenske, hrvatske i srpske - koje su već bile u ofanzivi sa željom zadobivanja što bolje pozicije za svoj narod i matičnu republiku u predstojećim odsutnim političkim događanjima, a kojima se nastojala redefinirati Federacija, Jugoslavija nije ni mogla biti u boljem položaju.

Također, postajalo je jasno da Jugoslavija gubi položaj koji je imala prije početka demokratskih promjena koje su zahvatile Istočni blok, prije svih Poljsku, Mađarsku i Čehoslovačku. Zapravo je poslije „urušavanja” SSSR-a izgubila strateški značaj koji je zadobila nakon 1945/1948. godine, tako da više nije bila „regionalna sila, ključna balkanska zemlja, koja razdvaja dvije super sile, utičući istovremeno na ideološku eroziju socijalističkog bloka”." O njenoj ulozi bilo je govora još ranije. Već u februaru 1980, dok se Josip Broz Tito nalazio u komi, u razgovoru u Beču Andreja Gromijka, sovjetskog ministra vanjskih poslova, i Cyrusa Vancea, državnog sekretara SAD-a, istaknut je zajednički stav i mišljenje da Jugoslaviji predstoji budućnost periferne balkanske države.

\section{Kontekst političkog izrastanja i sazrijevanja Adila Zulfikarpašića}

Komunistička ideja imala je velikog udjela u formiranju političkih stavova Adila Zulfikarpašića, a sindikalizam i okupljanje radništva predstavljali su najznačajniji oslonac komunistima u širenju ideologije, u čemu je i sam Zulfikarpašić vidio polje za djelovanje. Na temelju Privremenog pravilnika Glavnog radničkog saveza Jugoslavije, formirani su oblasni odbori, među 
njima i onaj za Bosnu i Hercegovinu 1922. godine. ${ }^{2}$ Među prvim socijalistima i sindikalistima kod Bošnjaka bio je Alija Alijagić (obješen u Zagrebu 1922), rodom iz osiromašene bijeljinske begovske porodice. Nakon Obznane (decembar 1920) priključio se ljevičarskoj terorističkoj grupi Crvena pravda, u kojoj su bili još neki poslije istaknuti pripadnici KPJ-a. Ipak je razvoj komunističke ideologije u Bosni i Hercegovini zaostajao za drugim južnoslavenskim područjima. Tridesetih godina 20. stoljeća niz pritužbi stizao je Centralnom komitetu (CK) zbog zapostavljanja Bosne i Hercegovine i nepostojanja partijske infrastrukture.3

Cimnazijski profesor Akif Šeremet (1899-1939) bio je jedan od poznatijih komunista koji je postao i članom CKKPJ-a. Nema sumnje da su on i nekolicina drugih Bošnjaka utjecali na širenje komunističkih ideja među bošnjačkom omladinom, približavajući ih tako ne samo jugoslavenskom već i širem evropskom kontekstu. Šeremeta je Josip Broz Tito 1939. godine isključio iz Partije i proglasio štetočinom koja je „varala Kominternu” i zajedno s drugim jugoslavenskim komunistima (Kosta Novaković, Sima Marković i Simo Miljuš) strijeljan je aprila 1939. godine. ${ }^{4}$ Također su bošnjački pisci tridesetih godina (Hasan Kikić, Rizo Ramić, Skender Kulenović i Safet Krupić) ostavljali traga među bošnjačkom omladinom i budili zanimanje za komunističke ideje. Dijelom na njihovim idejama izrasli su poznati partijski prvaci Asim Behmen (1899-1924), stolački omladinac, koji je u jednom trenutku predvodio PK SKOJ-a za Hrvatsku, i Rifat Burdžović (1913-1942), sandžački studentski lider, koji je studirao na Univerzitetu u Beogradu i krajem tridesetih bio član MKKPJ-a za Beograd.

Dakle, značajna skupina koja je promovirala i prihvatala komunističku ideologiju bili su studenti. Mladi i ambiciozni ljudi omeđeni teškim stanjem u monarhističkoj Jugoslaviji bili su skloni revolucionarnim i radikalnim idejama, težili ka promjenama i uspostavljanju ravnopravnijeg i sretnijeg društva. Vjerovatno je najznačajniju opservaciju o položaju bošnjačkog naroda i njegovim potrebama uradio Safet Krupić u tekstu Današnjica i mi. On je bio porijeklom iz Bosanske Krupe, a diplomirao je filozofiju i francuski jezik na Filozofskome fakultetu u Zagrebu 1934. godine. Revnosno je

\footnotetext{
2

Ibrahim Karabegović, Reformistički pravac u radničkom pokretu u BiH, Svjetlost, Sarajevo, 1979, str. 152.

3

Nedim Šarac, „Osvrt na politiku Komunističke partije u Bosni i Hercegovini pred Petu zemaljsku konferenciju 1940. godine", Prilozi, 1970, br. 6, str. 117-124

4

Pero Simić, „Tito sudi - Staljin strelja”, Večernje novosti, 4. 2. 2003, Dostupno na: http://www.novosti.rs/dodatni_sadrzaj/clanci.119.html:276059-Tito-sudi---Staljin-strelja (5. 5. 2018).
} 
pripadao grupi revolucionarnih marksističkih filozofa. Bavio se pretežno spoznajnom teorijom, a njegova najznačajnija studija bila je Filozofija i nauka. Baveći se bošnjačkim, ali i pitanjem svoje bošnjačke generacije, i on piše o zatečenosti ratom i ratnim dešavanjima, prepuštenosti događajima i potpunim nerazumijevanjem „nove stvarnosti”. ${ }^{\text {Koliko god da je Krupić }}$ bio prodoran, njegovi pogledi nisu dovoljno oslikavali unutrašnju dinamiku bošnjačkog političkog života, već su slijedili ideologiziranu sliku obračuna s reliktima nazadnih političkih odnosa. Ništa drugačije ovome izričaju nisu prilazili ni ostali bošnjački omladinci komunisti, koji su razvlašćivanje begovata vidjeli kao bolan, ali pozitivan historijski proces. No, svi oni, zapravo, vrlo jasno ističu jaku pripadnost i svijest o Bosni, njenoj naročitosti i posebnosti Bošnjaka u njoj. ${ }^{6}$

Sredinom tridesetih godina dolazi do toga da bošnjačka studentska populacija koja je studirala na univerzitetima u Beogradu i Zagrebu ozbiljnije pristupa komunističkom pokretu. Mahmut Bušatlija kao student i komunista na Beogradskom univerzitetu bio je član Uprave Udruženja bosanskohercegovačkih studenata „Petar Kočić”, koje je organizirao najizrasliji među bošnjačkim komunistima Avdo Humo, a u KPJ-u bio je od 1937. Tokom dvije godine napredovao je u organizaciji i od 1939. postaje dijelom rukovodstva univerzitetskog odbora KPJ-a. Kada se ima u vidu da je društvo, iako bosanskohercegovačko, a ne bošnjačko, nosilo ime Petra Kočića, nameće se mišljenje da je riječ o nastavku velikog i konkretnog identitetskog lutanja Bošnjaka.

Ipak, u pitanju Bosne i Hercegovine studenti su nalazili znatnu podršku u stavovima Komunističke partije, koja je stajala na poziciji narodne autonomije, što je eksplicitno potvrdila i na Petoj zemaljskoj konferenciji jula 1940. godine. Među učesnicima te konferencije, kao članovi pokrajinskih komiteta za BiH i SKOJ-a (Saveza komunističke omladine Jugoslavije), bili su Mahmut Bušatlija, Muhamed Kazaz, Pašaga Mandžić i Mujo Pašić.7 Jugoslavenski komunisti u tome vremenu su, kako je kazano, bili na stajalištu kako bosanskohercegovačke posebnosti tako i posebnosti Bošnjaka. Istina, kod ovoga drugog pitanja postojao je velik rascjep.

\footnotetext{
5 Šaćir Filandra, Bošnjačka politika u 20. stoljeću, Sejtarija, Sarajevo, 1998, str. 144-145. godine", Prilozi, 1970, br. 6 .
} 
No, unutar radničkog pokreta u Bosni i Hercegovini, što zbog bavljenja drugim, životnim temama, što zbog nedostatka inteligencije koja je mogla teorijski diskutirati o ovoj temi, pitanje Bosne i Hercegovine zapravo je bilo kao i u samom začetku, odnosno onako kako ga je još socijaldemokratija definirala - unitarističko jugoslavensko, sa srpskim karakterom Bosne i Hercegovine. ${ }^{8}$ Ovu činjenicu potvrdio je i Avdo Humo kada je kazao da od 1918. do 1938. godine Komunistička partija Jugoslavije nije imala definiran politički stav prema Bosni i Hercegovini zbog nedefiniranog stava prema Bošnjacima. Oni su tretirani kao vjerska skupina koja se tek treba nacionalno opredijeliti. Ovaj stav ponovo će pobijediti među komunistima 1945. godine.

Adil Zulfikarpašić je personificirao dinamičniji oblik aktivizma i opredijeljenosti. Kao adolescent je pristupio komunističkoj omladini, a 1937. godine je čak isključen iz fočanske gimnazije zbog sudjelovanja u organizaciji štrajka u lokalnoj drvnoj industriji. Pred Drugi svjetski rat vraćen je u Komunističku partiju nakon kratkog isključenja zbog ideoloških nesporazuma, poslije čega postaje njen izuzetno aktivan član. U februaru 1942. godine Adila Zulfikarpašića u Sarajevu su uhapsile ustaše i osudile na smrt, ali je zbog toga što je bio iz ugledne porodice i zato što su mu brata zaklali četnici pomilovan i osuđen na dvadeset godina robije. Ipak, nekako je uspio pobjeći i nastaviti partijski rad u Bosni i Hercegovini, koji kruniše formiranjem Više partijske škole. ${ }^{9}$ Ovakav politički razvoj Adila Zulfikarpašića svjedočio je o njegovom idealizmu i želji da društvene promjene budu brze i učinkovite. Nestrpljivost koju je ispoljavao u nekim trenucima bila je previše i za komunističku proaktivnu politiku. Nakon rata je u prvoj Vladi Republike Bosne i Hercegovine postavljen za pomoćnika ministra trgovine, što mu je omogućilo da vidi kako vodeći komunistički sloj ovladava materijalnim dobrima i živi ugodnim životom, dok masa tavori u neimaštini. Zbog toga je izgubio vjeru u mogućnost zavođenja socijalne pravde, te je odlučio napustiti državu i početi život na Zapadu. Po svemu sudeći je dijelio Đilasovo stanovište da su komunisti, s pozicija evropskog liberalizma, odigrali plemenitu ulogu u rješavanju nacionalnog pitanja, tako da je i mladalačke ideale mogao nalaziti u liberalnoj ideji kojoj je polahko pristupao i po kojoj će ostati upamćen.

8

Šaćir Filandra, Bošnjačka politika u 20. stoljeću, Sejtarija, Sarajevo, 1998, str. 137.

9

„Vakif: Vakif Bošnjačkog instituta - Fondacija Adila Zulfikarpašića”, Bošnjački institut - Fondacija Adila Zulfikarpašića, dostupno na: http://www.bosnjackiinstitut.ba/home/sadrzaj/37 (18. 6. 2018) 


\section{Djelovanje u dijaspori}

U dijaspori je Adil-beg svojski radio na bošnjačkom političkom organiziranju, a od 1954. godine bio je nastanjen u Švicarskoj. Relativno brzo, kako je kazano, pristupio je Liberalnoj internacionali i jedno vrijeme bio kontinentalni sekretar i član Izvršnog komiteta te političke strukture. Time je sebi otvorio put ka evropskim političkim i ekonomskim krugovima. Sljedeći korak koji je preduzeo bilo je okupljanje najuglednijih Bošnjaka u emigraciji radi stvaranja Bošnjačke demokratske organizacije, održavajući živu vezu s Bečom, u kojem je i boravio nakon emigriranja, a prije dolaska u Zürich.

U Beču, gdje je već djelovala novostvorena jezgra bošnjačke demokratske emigracije, počinje 196o. godine izlaziti političko-kulturni mjesečnik Bosanski pogledi, za koji su pisali ugledni bošnjački intelektualci i ličnosti iz javnog i političkog života predratne Jugoslavije. Vrlo važne ličnosti u bečkom krugu, ali i šire bili su dr. Smail Balić, vrijedni naučni radnik, koji je prema Austriji otišao još pred Drugi svjetski rat, i Teufik Velagić Tofa, mladomusliman koji je nakon robije i završenog Poljoprivrednog fakulteta u Zagrebu 1962. godine napustio Jugoslaviju. Po dolasku u emigraciju počeo je politički djelovati uz dr. Smaila Balića i Adila Zulfikarpašića, s kojim je kao član Liberalne internacionale učestvovao na raznim političkim skupovima. Sastanku Liberalne internacionale u Berlinu 1963. godine Velagić je prisustvovao kao član Odbora Liberalnog demokratskog savjeta Bošnjaka Muslimana, u kojem je jedno vrijeme bio i generalni sekretar.

Opća slika koja se formirala u vezi s Adilom Zulfikarpašićem, a na temelju njegovog djelovanja u emigraciji i pri povratku u domovinu, ima tri uporišne tačke kojima se njegova ličnost portretira. On je emigrantski političar, koji je, iako projugoslavenski nastrojen, predstavljao i demokratsku alternativu socijalističkoj autoritarnosti. Također je bio i politička avangarda zbog pripadanja evropskoj liberalnoj misli, koja je kao takva bila novost, posebno za bosanskohercegovačke prilike, čime je, zapravo, obogatio političku scenu. U vezi s tim je i njegovo istrajavanje na restauraciji građanskog društva nakon komunizma kao vida bazične društvene obnove i pristajanja uz razvijeni Zapad. I treća uporišna tačka je prepoznavanje Adil-bega kao nacionalnog preporoditelja u njegovom političkom i kulturnom djelovanju.

Pored ovog djelovanja Zulfikarpašić je nastojao graditi saradnju sa srpskim i hrvatskim emigrantskim krugovima, bivšim građanski orijentiranim političarima ili pobornicima takvih ideja. Demokratska alternativa, koja je nastojala objediniti čitavu jugoslavensku emigraciju i na čijem organiziranju je radio Ljubo Sirc upravo sa željom građenja jugoslavenskog demokratskog kapaciteta (Vladimir Predavec, Desimir Tošić, Vane Ivanović itd.), 
bila je vrijedan okvir unutar kojeg su se mogli kristalizirati stavovi. Upravo je ideja o konfederalnoj Jugoslaviji (sastanak u Sanstedu) bila jedna od značajnijih koju je ta grupa iznjedrila i, prema Adilu, Demokratska alternativa je imala dobro rješenje za čitavu Jugoslaviju. Čitava ta priča izgledala je kao djelovanje Jugoslavenskog odbora tokom Prvog svjetskog rata (1915-1918).

Druga grupacija s kojom je Zulfikarpašić nastojao blisko sarađivati bila je Oslobođenje (srpska emigracija), stvarnim baštinicima politike Ljube Davidovića i Milana Grola. Ako je Demokratska alternativa djelovala na općim principima, onda je Oslobođenje, barem ih je Zulfikarpašić takvim doživio, imalo sluha i takta za dogovaranje detalja. Najveći domet koji je napravljen, a koji je i Adil-begu bio bitan, bila je deklaracija kojom je kazano da nema promjene granica u nadolazećem raspletu u Jugoslaviji. Osobe koje su učestvovale u tim razgovorima, pored ovoga pitanja očuvanja granica, zagovarale su suštinsku reformu u Jugoslaviji koja mora proći bez ratnih dešavanja. Zapravo je ovakvim širokim djelovanjem Zulfikarpašić samo potvrđivao koliko je bio fokusiran (reklo bi se i zabrinut) na pitanje budućnosti Bosne i Bošnjaka kada otpočne neminovan proces demokratizacije Jugoslavije.

\section{Bošnjački politički tokovi pred slom SFRJ-a}

Sasvim jasna nespremnost bošnjačke političke elite unutar SKJ-a da promišlja postsocijalističku Jugoslaviju / Bosnu i Hercegovinu, upravo u vremenu kada je to bila nasušna potreba, otvorila je prostor do tada marginaliziranim i stigmatiziranim pojedincima i grupama da otpočnu s političkim aktivnostima. Gibanja na političkoj sceni u Bosni i Hercegovini kaskala su za onime što se događalo drugdje, posebno u Beogradu i Zagrebu. Zbog toga su pogledi nadolazećih političkih snaga unutar bošnjačkog korpusa - bošnjačkim antikomunistima i političkim liberalnim aktivistima - bili okrenuti u prvom redu ka hrvatskoj prijestolnici Zagrebu i švicarskom gradu Zürichu. Zagreb je postajao značajan zbog prestanka „hrvatske šutnje” i otpočetih demokratskih procesa, ali i jakog bošnjačkog političkog establišmenta okupljenog oko Zagrebačke džamije. Zürich, pak, jer je tamo živio Adil Zulfikarpašić, najznačajniji bošnjački politički disident, izuzetan privrednik i utemeljitelj Bošnjačkog instituta osnovanog 6. juna 1988. godine u tome švicarskom gradu.

Upravo ova činjenica, okretanje bošnjačke političke avangarde ka Zapadu, zorno svjedoči o svjetonazorskom i ideološkom profilu novonastajuće političke snage. Osvajanje slobode na principima demokratskog (kapitalistič- 
kog) svijeta koji prepoznaje prava pojedinca i prava kolektiviteta te baštini različitost kao jednu od temeljnih vrijednosti, iskovanu i osvojenu u 20. stoljeću, prirodno je uokvireno u osnovne postulate bošnjačkog političkog faktora.

Lider bošnjačke avangarde Alija Izetbegović, skupa s ondašnjim saradnicima, obavio je niz razgovora s Adilom Zulfikarpašićem o osnivanju političke stranke. Zulfikarpašić je posvjedočio da je krajem 1989. godine u Zürichu bio dogovoren okvir - on nije mogao putovati u BiH/SFRJ zbog komunističkih vlasti - i dogovoreni su osnivački principi. ${ }^{10}$ Ipak se relativno brzo pokazalo da ovaj dvojac razmišlja različito o temelju na kojem se stranka treba izgraditi. Dok je Zulfikarpašić bio zagovornik bošnjaštva, Izetbegović je stajao na poziciji muslimanstva. Adil-begu je bosanskohercegovački okvir bio i više nego dovoljan, dok je Aliji Jugoslavija predstavljala prostor na kojem će buduća politička stranka djelovati.

Izetbegović je zagovarao da stranka bude koncipirana poput Spahine Jugoslavenske muslimanske organizacije (JMO), tako da je podržavao osnivanje Muslimanske stranke u Jugoslaviji (MSUJ). ${ }^{11}$ Razlog tome je ležao u činjenici da je veliki broj izrastajućih bošnjačkih političara bio sklon i veoma pozitivno gledao na Spahinu politiku. Koliko god izgledala kontroverzna, ipak su je smatrali dobrim bošnjačkim odgovorom u vrijeme Kraljevine SHS / Jugoslavije i velike kušnje kroz koju je prolazila Bosna i Hercegovina, ali i bošnjački narod napose.

Izetbegovićevo obrazloženje ovakvog stava je bilo kako je Bošnjacima bila potrebna probosanska i promuslimanska politička organizacija koja bi okupila narod koji živi na dugom pojasu od Novog Pazara do Cazina, izmiješan sa Srbima i Hrvatima. ${ }^{12}$ Argument izmiješanosti stanovništva imao je težinu i opravdanje, dok je uspjeh takve ideje, dakako, bio pod znakom pitanja. U ovome pitanju vidljiv je i različit pristup ovoga dvojca: Zulfikarpašićev partikularizam i Izetbegovićev univerzalizam su se na neki način odvajali kao dva stava koji svjedoče o odnosu pragme i principa.

10

Jens Martin Eriksen, Frederik Stjernfelt, Scenografija rata. Nova putovanja u Srbiju i Bosnu, Helsinški odbor za ljudska prava u Srbiji, Beograd, 2010, 216-217.

11

Više o Mehmedu Spahi i JMO-u vidjeti: Husnija Kamberović, Mehmed Spaho (1883-1939). Politička biografija, VKBI, Sarajevo, 2009 .

12

Alija Izetbegović, Sjećanja. Autobiografski zapisi, GIK OKO, Sarajevo, 2005, str. 77. 
Ipak, obojica su smatrala da u demokratskom ozračju i uz uvažavanje posebnosti i različitosti južnoslavenskog političkog spektra diskusija treba biti vođena na temelju narodnog predstavljanja. Nema sumnje da je kod Zulfikarpašića bilo i elitizma, njegov liberalizam je bio starog kova, tako da je aristokratsko porijeklo bivalo prednošću, a ne mahanom. To ga je činilo nesklonim populizmu, što je jasno pokazao 1990/91, a što je u političkom smislu ogroman nedostatak.

Zbog ovakvog odnosa naglašavao je kako je „muslimanska buržoazija”, misleći dijelom i na begovat, pred Drugi svjetski rat dominantno bila na ljevici, što će reći predstavljala je progresivnu avangardu. Ovakvo njegovo razmišljanje je dosta interesantno jer je izrastanje bošnjačke buržoazije u tome vremenu fenomen koji još nije dovoljno istražen i kontekstualiziran. No, ovo Adil-begovo razmišljanje dovelo je i do njegovog objašnjenja o bošnjačkom pristupanju Komunističkoj partiji, koja je postepeno jačala u Jugoslaviji, uprkos njenom zabranjivanju i šikaniranju. S druge strane, ovakav pristup emanira i utjecaj sredine u kojoj je živio Adil-beg, tj. pokazuje njegovo usvajanje i naslanjanje na elitistički koncept dosta prisutan u švicarskim protestantskim kantonima.

\section{Zaključak}

Demokratizacija Jugoslavije doživjela je strašan slom zbog mesijanskih ideja dvaju nacionalizama, srpskog i hrvatskog, koji su doveli do četiri rata na tlu bivše države, od kojih je agresivni pohod na Bosnu i Hercegovinu bio najbrutalniji. U tom i takvom vojno-političkom karakazanu razvijala se ukupna bošnjačka politika. Značajan sudionik većine bitnih političkih događaja bio je Adil Zulfikarpašić. Svojim političkim iskustvom i idejom kojoj je pripadao predstavljao je dah evropejstva i drugačijeg političkog izričaja, a s Alijom Izetbegovićem bio je dijelom posebnog narodnog predstavljanja. Naime, obojica su, za razliku od svih drugih republičkih/narodnih rukovodstava u SFRJ, dolazili izvan bivšeg socijalističkog sistema. Nisu bili članovi partije niti državnog aparata. Ova činjenica, kada se govori o Bošnjacima, ima ogroman značaj i poziva na daljnji istraživački poduhvat i eksplanatorni postupak.

Kao takav i s takvim pozicijama Adil Zulfikarpašić je nesumnjivo bio spreman dati enorman doprinos tranziciji društva i države od socijalističkog mrtvila ka kapitalističkoj živosti. Iako su reforme u tom smislu polahko stizale u Jugoslaviju tokom druge polovine osamdesetih, okoštali aparat morao je biti demontiran u potpunosti da bi ljudi i njihove ideje u koje se svrstava i Zulfikarpašić i njegov liberalni svjetonazor mogli implementirati 
novi prijeko potrebni koncept. Spomenuta agresivnost malih nacionalizama spriječila je ovu tranziciju i dovela do transformacije društva na zasadama postkonfliktnih, postgenocidnih i postratnih trauma u kojima je Zulfikarpašićev istančani politički habitus teško nalazio put. Na taj način je svakako, pored svih drugih nepravdi, učinjena nepravda i njemu lično, ali i Bosni i Hercegovini jer je jedan humanistički pristup koji je inklinirao kulturnom i civilizacijskom skoku onemogućen u začetku. Upravo taj skok je Bošnjacima trebao otvoriti vrata ka izgradnji političke zrelosti za koju su imali kapacitet. 


\section{Political Pluralism and Democratization of Yugoslavia}

\begin{abstract}
This article discusses the political development of Adil Zulfikarpašić and his role during the democratization process in Yugoslavia and Bosnia o Herzegovina, respectively. An overview of the emergence of the communist idea in Bosnia and Herzegovina during the 1930s and 1940s, as well as its bearers, among whom was Zulfikarpašić, was given. The significance of this ideology, together with the events of the Second World War, is great for Zulfikarpašić because it stood in the way of his complete political development and was the ,provocateur" of his further ideological formation. As a clearly oriented liberal of the European environment, he represented a true breath of democracy during the change of socio-political rela-
\end{abstract}

tions, and for Bosniaks he was a proof of their desire for a truly democratic society and order. It was right from these liberal foundations, fully nationally aware and committed to Bosnia o Herzegovina, that Adil Zulfikarpašić, during his stay in Switzerland, sought to act and cooperate with Yugoslav emigrants and political dissidents residing in European countries. On that experience he also built his own attitude towards the political reality in Yugoslavia and his approach in finding a solution to the drama that was ongoing.

KEYWORDS: democratization, Yugoslavia, Adil Zulfikarpašić, Bosnia \& Herzegovina, politics, Party of Democratic Action 